WIDER Working Paper 2017/78

Anti-discrimination measures in education

A comparative policy analysis

Amanda Lenhardt, ${ }^{1}$ Ella Page, ${ }^{2}$ Moizza Binat Sarwar, ${ }^{3}$ and Andrew Shepherd ${ }^{3}$

April 2017

United Nations University World Institute for Development Economics Research

wider.unu.edu 
Abstract: Efforts to tackle discrimination in access to basic services have shown mixed results in different country settings. This study examines the positive and negative outcomes attributed to anti-discrimination measures adopted in different country contexts and analyses the factors contributing to these outcomes, with a specific focus on anti-discrimination measures in education. An analysis of trends in inequalities in human development is used to identify three countries that have seen positive change in reducing inequalities and three countries that have seen negative change. This is followed by a literature review exploring the factors that have contributed to the changes observed in these six cases. We find that reductions in inequalities have been achieved in those countries where targeted measures have gone alongside universal measures, where the constitution is used to generate an equity-focused political discourse, and where evidence on exclusion from education has been taken up politically.

Keywords: inequality, anti-discrimination measures, poverty, education, public policy JEL classification: I24, I32, D63, J15, H75

${ }^{1}$ Save the Children, London, UK; ${ }^{2}$ Independent Consultant, London, UK; ${ }^{3}$ ODI, London, UK; corresponding author a.shepherd@odi.org.uk

This study has been prepared within the UNU-WIDER project on 'Disadvantaged groups and social mobility'.

Copyright (C) UNU-WIDER 2017

Information and requests: publications@wider.unu.edu

ISSN 1798-7237 ISBN 978-92-9256-302-8

Typescript prepared by Lesley Ellen.

The United Nations University World Institute for Development Economics Research provides economic analysis and policy advice with the aim of promoting sustainable and equitable development. The Institute began operations in 1985 in Helsinki, Finland, as the first research and training centre of the United Nations University. Today it is a unique blend of think tank, research institute, and UN agency — providing a range of services from policy advice to governments as well as freely available original research.

The Institute is funded through income from an endowment fund with additional contributions to its work programme from Denmark, Finland, Sweden, and the United Kingdom.

Katajanokanlaituri 6 B, 00160 Helsinki, Finland

The views expressed in this paper are those of the author(s), and do not necessarily reflect the views of the Institute or the United Nations University, nor the programme/project donors. 
This study is part of a wider desk-based review of the role of anti-discrimination and affirmative action policies and measures in progress towards the eradication of extreme poverty. Whereas the main review (Marcus et al. 2016) has sought out evaluative literature from across the developing world on this issue, this study is an attempt to start from positive and negative outcomes, which could possibly be attributed to anti-discrimination measures, and to analyse the factors contributing to these outcomes to see if anti-discrimination measures figure in the analysis.

One reason for this approach is that the literature on anti-discrimination measures is very focused on a small number of countries, principally Brazil, India, and South Africa. It was hoped that focusing on outcomes would reveal a different group of countries, and this did indeed happen.

Using a comparison of human development outcomes (under-5 mortality, child stunting, and primary school completion) between the most and least deprived ethnic groups gave us a number of positive and negative cases, the clearest of which were: Cambodia, Ethiopia, and Ghana (positive); and Nigeria, Peru, and Uganda (negative). These six countries are the focus of the subsequent analysis of the study. A literature review was then carried out to explore the factors explaining the changes (reduced/greater inequality) observed in each case. In order to make this feasible within the resources and time frame available, this was focused on educational access.

The findings from the individual country cases are then summarized by a comparative analysis of the common factors that have contributed reductions in inequalities in education in this set of countries. There are three main explanatory factors emerging from this analysis: the achievement of a combination of universal and group-specific or targeted measures and the utility of a constitution which generates an equity-focused political discourse; the importance of evidence on exclusion from education, but also the political environment which can make use of it; and finally the utility of mother-tongue education in the initial years.

\section{Outcome analysis}

We identify two possible approaches to investigating the relationship between anti-discrimination measures and poverty reduction. One approach is to examine countries where anti-discrimination measures have been implemented and the other is to examine countries where changes in indicators of discrimination or discriminatory practices have occurred, though the causes of such changes are not necessarily known.

In this paper, we have opted for the latter approach in order to emphasize the relationship between discrimination and multidimensional poverty, and to keep an open-ended approach to the question of what causes poverty reduction. In particular, we have sought to identify and observe change in outcomes of discrimination which are relevant for poverty and for which change can be traced over time.

Broadly speaking, two types of outcomes are relevant: i) income and access to income opportunities; and ii) human development outcomes. The hypothesis is that discriminated groups will perform worst in these outcomes. It follows that discrimination can be measured by looking at inequalities in these outcomes between relevant groups, with changes in inequalities being 
indicative of changes in discrimination. Due to data limitations, this paper will only examine human development outcomes. ${ }^{1}$

We begin by identifying countries where inequalities between different social groups in human development outcomes have either decreased or increased over time. This quantitative analysis is then used to select three positive cases (where inequalities have decreased) and three negative cases (where inequalities have increased) to study which anti-discrimination measures have been adopted (if any) and to review evaluations of the effectiveness of those measures. We employ under-5 mortality, under-5 stunting, and primary school completion as basic indicators of health, nutrition, and education outcomes.

The data sources used for this analysis are taken from the Demographic and Health Surveys (DHS) and Multiple Indicator Cluster Surveys (MICS) which collect data on population, health, HIV, and nutrition for around 100 countries. DHS and MICS are useful for this analysis because they employ standardized measures across different countries and over time, and because a subset of them also collects information on respondents' identity (including gender, language, ethnicity, and region). This enables analysis of human development outcomes by relevant social groups to reveal horizontal inequalities. ${ }^{2}$ Due to data limitations, only 22 countries are analysed, covering time periods between 2000 and 2014.

To limit the scope of the quantitative analysis, we focus on trends in disparities in human development outcomes between ethnic groups within countries. Regions within countries are used for those countries where data on ethnicity is not available but where regions are considered a reasonable proxy for ethnicity due to high regional concentrations of particular ethnic groups ${ }^{3}$. We employ ethnic inequalities in human development as our indicator of change in discriminatory outcomes based on the assumption that inequalities associated with identities that are ascribed at birth — such as ethnicity, race, and caste-lead to some of the most enduring forms of poverty, ${ }^{4}$ and are therefore priority targets for anti-discrimination policies.

As part of our analysis, we also explore inequalities in these outcomes according to gender, and the findings show positive trends in reducing inequalities between girls and boys in all countries on education (with the exception of Burkina Faso), while gaps in under-5 health and nutrition outcomes tend to disadvantage boys due to innate biological reasons (UN Inter Agency Group for Child Mortality Estimation 2015).

To measure the trajectory of inequalities in human development outcomes as either positive or negative, we calculate the ratio between the group with the lowest average outcomes against the group with the highest average outcome in each country for each indicator. This ratio tells us how far behind the most disadvantaged ethnic group is from the most advantaged group. We then

\footnotetext{
${ }^{1}$ DHS do not include information on household- or individual-level income. The nearest approximation is an asset index that categorizes households into quintiles. This poses a challenge to carrying out distributional analysis to explore levels of inequality. Due to this limitation we have chosen to focus on human development outcomes in this paper.

2 Horizontal inequalities refer to inequalities between groups of people-such as ethnic, religious, and spatially distinguishable groups or gender-versus vertical inequalities which refer to inequalities between individuals.

${ }^{3}$ Using secondary sources on the demographic composition of regions within countries, we identified those regions that were identified as being predominantly populated by ethnic minority groups as suitable proxies.

${ }^{4}$ See Kabeer (2010), Sumner (2012), and Lenhardt and Samman (2015).
} 
measure the relative change in this ratio over two survey periods to determine whether it is increasing or decreasing. Table 1 summarizes these results.

Table 1: Relative change in inequality (ratio) between the most disadvantaged group and the least disadvantaged group (\%)

\begin{tabular}{lllll}
\hline & Under-5 & U-5 stunting & Primary & Trend \\
mortality & +64.0 & -2.5 & -69.0 & Positive \\
\hline Benin & +33.3 & +52.3 & -16.7 & Negative \\
\hline Bolivia & +32.9 & +7.6 & -11.9 & Negative \\
\hline Burkina Faso & -6.7 & +12.2 & -51.3 & Positive \\
\hline Cambodia & -52.4 & -42.4 & $\mathrm{n} / \mathrm{a}$ & Positive \\
\hline Cameroon & -13.3 & +27.2 & -2.6 & Positive \\
\hline Columbia & -55.4 & -48.7 & -36.4 & Positive \\
\hline Republic of Congo & -11.9 & +12.1 & -39.0 & Positive \\
\hline Ethiopia & -2.3 & +37.6 & $\mathrm{n} / \mathrm{a}$ & Uncertain \\
\hline Gabon & +36.4 & -36.8 & -31.8 & Positive \\
\hline Ghana & +20.2 & -10.7 & $\mathrm{n} / \mathrm{a}$ & Uncertain \\
\hline Guinea & $\mathrm{n} / \mathrm{a}$ & -0.5 & -55.5 & Positive \\
\hline Kenya & +93.8 & +96.7 & +131.2 & Negative \\
\hline Madagascar & +6.0 & -15.0 & $\mathrm{n} / \mathrm{a}$ & Uncertain \\
\hline Malawi & +27.9 & +28.4 & $\mathrm{n} / \mathrm{a}$ & Negative \\
\hline Mozambique & +12.5 & +0.1 & -37.1 & Uncertain \\
\hline Nepal & -3.6 & +60.5 & +13.4 & Negative \\
\hline Nigeria & -17.3 & +176.5 & -7.1 & Uncertain* \\
\hline Peru & +160.9 & -16.3 & $\mathrm{n} / \mathrm{a}$ & Uncertain \\
\hline Philippines & -10.6 & -25.7 & -16.4 & Positive \\
\hline Senegal & +108.2 & +165.0 & -16.5 & Pogative \\
\hline Uganda & +60.8 & -33.7 & -20.9 & \\
\hline Zimbabwe & +6.9 & -5 & & \\
\hline
\end{tabular}

Notes: $\mathrm{n} / \mathrm{a}$ refers to unavailable. Figures were not available over time for these countries. ${ }^{*}$ Peru is classified as uncertain due to the high increase in under-5 stunting alongside decreases in under-5 mortality and primary completion.

Source: Authors' calculations.

Based on these trends, we identify countries that have seen a decrease in inequality in at least two human development indicators as positive cases (Benin, Cambodia, Cameroon, Columbia, Republic of Congo, Ethiopia, Ghana, Kenya, and Senegal) and countries that have seen an increase in at least two indicators as negative cases (Bolivia, Burkina Faso, Mozambique, Nigeria, Uganda, and Zimbabwe). We classify those countries with small changes or missing data as uncertain, one of which we explore in the subsequent policy analysis as a case (Peru) where inequalities are among the highest in the world and where there has been the largest increase in inequality in a single dimension—child mortality.

To select a broad sample of countries spanning different levels of overall discrimination, country income, and geographical spread, we then pair these findings with the Minorities at Risk classification of discrimination against minority groups in each country ${ }^{5}$ as well as the World Bank

5 The Minorities at Risk database (Minorities at Risk Project 2009) has tracked 284 politically active ethnic groups from 1945 to 2006 to identify groups that 'actively suffer from, or benefit from, systematic discriminatory treatment'. We use the 'economic exclusion' index, reflecting the impacts of discrimination on material poverty. Groups are classified as: 'no discrimination; neglect/remedial policies; social exclusion/neutral policy; exclusion/repressive'. We 
country income classifications (see Table 2). Based on this pairing and considerations of available literature on each country, we identify Ethiopia, Ghana, and Cambodia as positive cases and Uganda, Nigeria, and Peru as negative cases.

Table 2: Case selection—level of discrimination (Minorities at Risk Project 2009) and income classification:

\begin{tabular}{|c|c|c|c|}
\hline Economic discrimination & LIC & LMIC & UMIC \\
\hline No discrimination & $\begin{array}{l}\text { Guinea } \\
\text { Madagascar }\end{array}$ & & \\
\hline $\begin{array}{l}\text { Neglect/remedial policies } \\
\text { Significant poverty and under-representation in desirable } \\
\text { occupations due to historical marginality, neglect, or restrictions. } \\
\text { Public policies are designed to improve the group's material well- } \\
\text { being. }\end{array}$ & Ethiopia & $\begin{array}{l}\text { Ghana } \\
\text { Philippines }\end{array}$ & \\
\hline $\begin{array}{l}\text { Neglect/no remedial policies } \\
\text { Significant poverty and under-representation due to historical } \\
\text { marginality, neglect, or restrictions. No social practice of } \\
\text { deliberate exclusion. Few or no public policies aim at improving } \\
\text { the group's material well-being. }\end{array}$ & Uganda & $\begin{array}{l}\text { Bolivia } \\
\text { Congo Rep. } \\
\text { Kenya } \\
\text { Senegal }\end{array}$ & \\
\hline $\begin{array}{l}\text { Social exclusion/neutral } \\
\text { Significant poverty and under-representation due to prevailing } \\
\text { social practice by dominant groups. Formal public policies } \\
\text { towards the group are neutral or, if positive, inadequate to offset } \\
\text { active and widespread discrimination. }\end{array}$ & & Cameroon & Peru \\
\hline $\begin{array}{l}\text { Exclusion/repressive } \\
\text { Public policies (formal exclusion and/or recurring repression) } \\
\text { substantially restrict the group's economic opportunities by } \\
\text { contrast with other groups. }\end{array}$ & $\begin{array}{l}\text { Cambodia } \\
\text { Zimbabwe }\end{array}$ & Nigeria & Colombia \\
\hline
\end{tabular}

Notes: Level of discrimination definition drawn directly from the Minorities at Risk database. * Missing from Minorities at Risk database: Benin, Burkina Faso, Mozambique, Gabon, Malawi, Nepal.

Source: Authors' illustration based on Minorities at Risk Project (2009).

Before turning to the policy analysis of these six countries, we also consider the trends in human development outcomes for each of the ethnic groups identified in the quantitative analysis to help inform our analysis. This is done to highlight which groups in these six countries have seen their human development outcomes improve relative to the most advantaged groups in the positive cases and those that have seen their human development outcomes fall further behind in the negative cases. An overview of these groups' human development trends is provided in Figures 1 and 2 .

Among the positive cases, Cambodia has seen the largest relative decrease of inequality in primary school completion between ethnic minority regions and the capital, Phnom Penh. Ethiopia and Ghana have also seen significant decreases of inequality in primary completion. Ghana was the only country among the positive cases to see a decrease in stunting inequalities, while Ethiopia has seen the largest decrease in inequality in under-5 mortality.

use the worst ranking of any group in a country to classify the country as a whole into one of these categories. 
Figure 1: Change in inequalities - positive cases

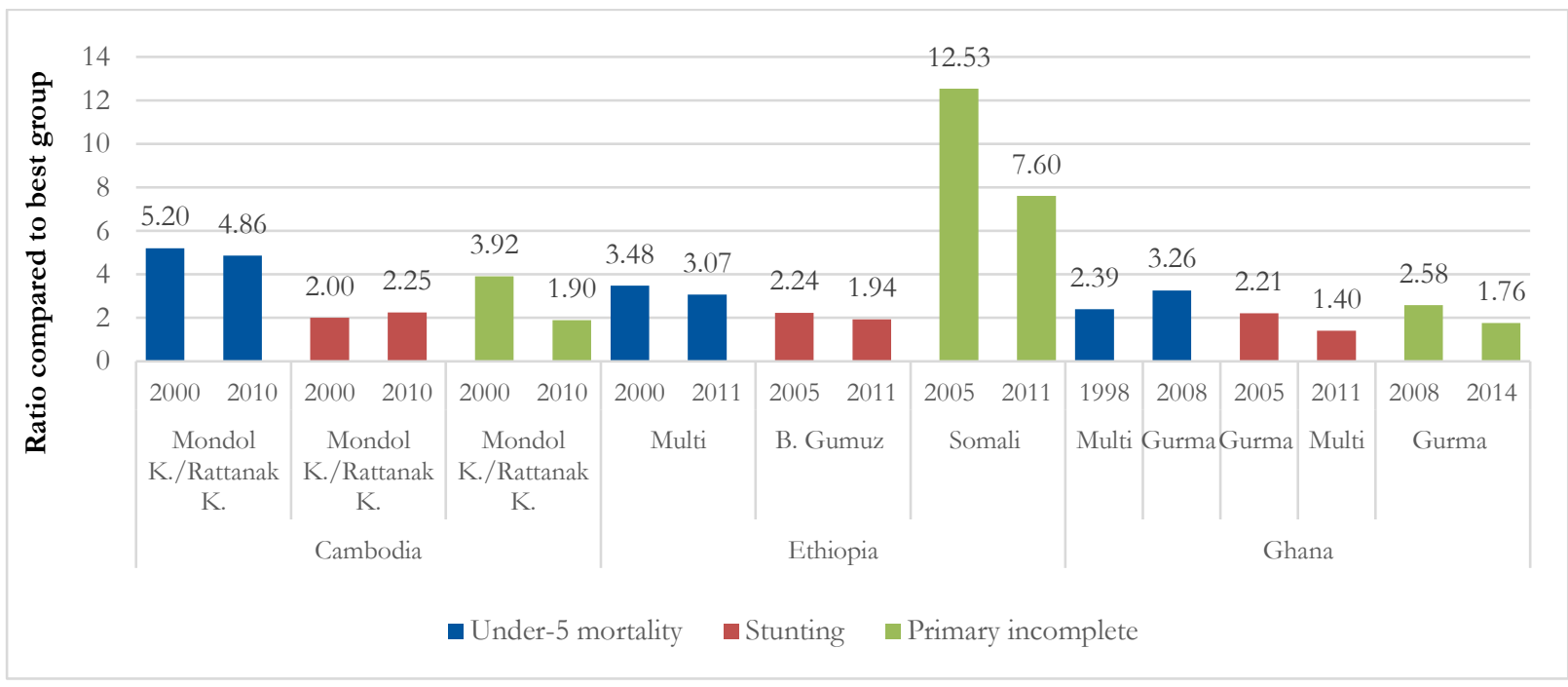

Note: 'Multi' refers to ethnic groups or regions that were combined to obtain a sample large enough to be representative (a minimum of 250 observations). Where groups are below 250 , they are combined with the next ranked group.

Source: Authors' calculations.

Among the negative cases, all countries saw some increase in inequality in stunting, with the Huancavelica region of Peru showing the largest increase from around five times higher rates than a combination of small advantaged regions to a staggering 14 times higher in 2012. Inequalities in primary completion increased in Nigeria, and both Peru and Uganda also saw increases of inequalities in child mortality.

Figure 2: Change in inequalities—negative cases

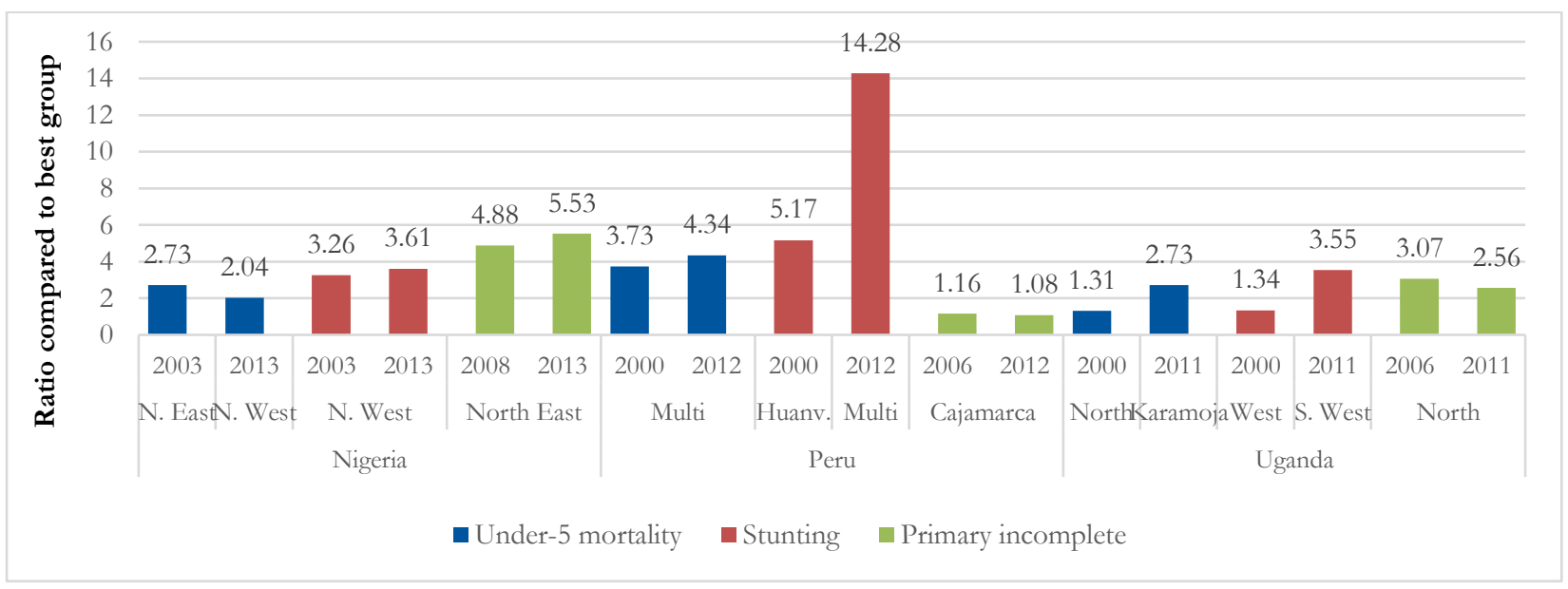

Note: 'Multi' refers to ethnic groups or regions that were combined to obtain a sample large enough to analyse (a minimum of 250 observations). Where groups are below 250, they are combined with the next ranked group.

Source: Authors' calculations.

Across the entire sample of countries, we find that the majority have seen some decrease in inequalities in primary school completion (14 out of 16 countries), while fewer have seen similar progress in reducing inequalities in stunting (10 out of 22 countries) and child mortality ( 9 out of 21 countries). Given that the most progress in reducing inequalities has been seen in primary school completion, we focus our analysis on policies in the education sector to analyse whether anti-discrimination policies have been a contributing factor. 
In each case, first a timeline is presented linking major developments in the country's politics, poverty reduction policies, and education sector, followed by a detailed analysis of the general political, economic, and social context together with relevant educational and other policies, specific programmes, and any resulting trends. There is a focus on the most deprived groups and how they have fared.

\subsection{Cambodia}

Table 3 sets out the timeline and major developments for Cambodia.

Table 3: Cambodia timeline

\begin{tabular}{ll}
\hline Year & Development \\
\hline 1993 & $\begin{array}{l}\text { First competitive elections following the peace accords lead to the adoption of a new } \\
\text { constitution and resumption of external support. }\end{array}$ \\
\hline $2001-05$ & $\begin{array}{l}\text { Second Socio-Economic Development Plan introduces the principles of broad-based and } \\
\text { sustainable economic growth, social and cultural development, the sustainable management } \\
\text { and use of natural resources, and improvement in good governance. }\end{array}$ \\
\hline 2001 & $\begin{array}{l}\text { First Education Sector Strategic Plan adopted and introduction of universal primary education } \\
\text { (UPE). }\end{array}$ \\
\hline 2002 & $\begin{array}{l}\text { Education Sector Support Programme acknowledges the need for bilingual curriculum in order } \\
\text { to reach population in Ratanakiri and Mondukiri-includes scholarships and training of ethnic } \\
\text { minority teachers. }\end{array}$ \\
\hline 2003 & $\begin{array}{l}\text { Five scripts or alphabets were approved in Ratanakiri and Mondulkiri Province all of which use } \\
\text { Khmer language symbols. }\end{array}$ \\
\hline $\begin{array}{l}\text { Rectangle Strategy adopted-designed as a comprehensive socio-economic development } \\
\text { plan with pillars of: good governance; enhancement of the agricultural sector; further } \\
\text { rehabilitation and construction of physical infrastructure; capacity building and human resource } \\
\text { development (this includes enhancing the quality of education); and private sector } \\
\text { development and employment generation. }\end{array}$ \\
\hline $\begin{array}{l}\text { Government announces that it will formally offer bilingual education to indigenous students' up } \\
\text { to grade } 3 \text { in five provinces. }\end{array}$ \\
\hline $\begin{array}{l}\text { Ministry of Education, Youth and Sport developed the Guidelines on Implementation of } \\
\text { Education for Indigenous Children in Highland Provinces, the first formal policy document on } \\
\text { bilingual education. }\end{array}$ \\
\hline Adoption of the first National Master Plan for the inclusion of Children with Disabilities. \\
\hline 2006
\end{tabular}

Source: Authors' illustration.

Cambodia's troubled political history has had severe long-term consequences for the development and functioning of the education sector. During the genocide between 1975 and 1979 at least 1.7 million people were killed, and educated and skilled people were particularly targeted (Greenhill 2013). Described as starting 'below ground zero' by the government (IMF 2006), the genocide left a lack of skilled or educated personnel and destroyed infrastructure. Another legacy was a political culture that prioritizes stability and is based on a neo-patrimonial system that favours informal systems, distorts bureaucratic accountability, and negatively impacts the delivery of public services including education (Chea et al. 2008).

Education has been a priority for the government since the 1993 peace accords as part of a commitment to develop the human resources necessary for economic growth. The government is committed to providing nine years of compulsory free education (Royal Government of Cambodia 2003). The budget of the Ministry of Education has risen by 88.2 per cent from 2007-2011 and in 2015 reached US $\$ 497$ million, an increase of 28.2 per cent from 2014 . The Government of Cambodia states that its spending priorities have been the provision of schools, scholarships, and school feeding programmes for the most vulnerable groups and institutional capacity development 
(Royal Government of Cambodia 2014). The education sector has also benefited from the post2013 election reforms which have also promised increased wages for teachers (ADB 2014).

National political discussions around education have tended to be subsumed in wider discussions about creating economic growth. In the competitive 2013 elections the ruling Cambodia People's Party continued to emphasize their record of economic growth and peace and security (The Economist 2013), while the new opposition party, the Cambodia National Rescue Party, campaigned on issues around corruption, nepotism, and growing economic inequality (Chheang 2013) and a used a strong anti-Vietnamese rhetoric (The Economist 2013).

Cambodia has made significant overall progress in education since 2000. Between 2000 and 2010 the rate of children that have never been to school fell from 26 per cent to 11 per cent, and primary school completion rose from 38 per cent to 67 per cent (UNESCO 2016). There has also been improvement in gender parity in primary and secondary school enrolment over this period-the gender parity index for gross enrolment in upper secondary rose from 0.50 in the 2002-03 school year to 0.93 in the 2012-13 school year. Initial gender disparities were lower in primary education, but the gender parity index reached 0.93 in 2012-2013. In the 2010-11 school year the overall rate of children enrolled in primary school was 95.2 per cent and the 2014 DHS survey shows net primary school attendance at 82.4 per cent with a gender parity index of 1.02 (National Institute of Statistics, Directorate General for Health, and ICF International, 2015).

Spending by international partners on Cambodia's education sector seems to be increasingly focused on secondary education and technical education as challenges have emerged. As Kitamura et al. (2016) argue, the education system has been beset by corruption in the form of informal fees, bribery, and redirection of budgeted money. For example, recent anti-corruption reforms around the national grade 12 examinations have dropped the pass rate from 80 per cent to 40 per cent and there are strong concerns that even students with secondary education do not have the skills needed to secure employment in a rapidly developing economy. The World Bank has supported the CESSP scholarship programme for Lower Secondary School Attendance, which has been shown to successfully increase enrolment for boys and girls (Filmer and Schady 2009; Ferreira et al. 2009) while the Asian Development Bank partnership strategy for 2014-18 includes school building, technical and vocational training, and support for the reform of the education system (ADB 2014).

Assessments by the Ministry of Education (2006, 2007, 2008) showed challenges in enrolment in and completion of secondary education, achieving quality learning, and reaching the most marginalized and remote groups living in Mondulkiri and Ratanakiri province (Royal Government of Cambodia 2014; Kitamura et al. 2016). Mondulkiri and Ratanakiri has been home to around two-thirds of the indigenous population of Cambodia (Minority Rights Group International 2008). There are two linguistic families within the indigenous population: the Autro-Thais made up of the Jari in Ratanakiri, and Môn-Khmner (which includes the Brao), Khmer Khe, Kravet, Kreung, Kraol, Lun, Mel, Phnong Kuy, and Thmaun ethnic groups (ADB 2002). ${ }^{6}$

Within primary education, recent government planning documents recognize that remote ethnic minority groups have been left behind and a more comprehensive policy for inclusion has been developed and implemented (IMF 2006; Royal Government of Cambodia 2014). Mondulkiri and Ratanakiri province, the region where most minority groups live, ${ }^{7}$ lags behind across all the

\footnotetext{
${ }^{6}$ Note: the government documentation tends to talk about regions and areas rather than ethnic groups.

${ }^{7}$ The Cham, Vietnamese, Ethnic Loa, and Chinese make up the largest minority groups in Cambodia. The Cham in particular appear to be well integrated-they make up the majority of ethnic minority representatives in the national
} 
available education indicators and, while gaps tend to be decreasing, they remain stark. For example, among out-of-school children the gap between these provinces and the average has decreased from 48 per cent to 28 per cent between 2000 and 2010; and for those with less than four years of education the gap decreased from 39 per cent to 28 per cent between 2000 and 2010. This compares to a rate of only 5 per cent for those with less than four years of education in Phnom Penh (UNESCO 2016)

Disparities have been worst in upland areas of Ratanakiri, according to the Asia Development Bank. In 2002 only 32 per cent of highland villages had schools, and where schools existed they mainly offered only grades 1 and 2, and teaching was conducted only in Khmer, which students and community members could not understand (ADB 2002).

The move towards providing bilingual education in remote areas of Cambodia has been slow as the extent and persistence of the lag between Mondulkiri and Ratanakiri and the rest of country has become evident. In her exploration of the relationship between minority groups and the state of Cambodia, Ehrentraut (2013) argues that the project of Khmer nation building and sense of geopolitical insecurity in the relationship with Viet Nam and Thailand has contributed to a political discourse which was reluctant to recognize minority claims and continues to hold fears of secession or the creation of a separate state.

The first pilot projects in providing bilingual education began in 1997, with funding from UNESCO, and were accompanied by linguistic research to create written alphabets using Khmer script of five of the 25 minority languages used in Cambodia (Thomas 2003; UNESCO 2011). ${ }^{8}$ In 2002 these pilots were expanded and in 2006 the government made its first official commitment providing bilingual education. Commitment has grown since then and expanding bilingual education is now a key commitment in the 2014-18 Education Sector Strategic Plan. The number of languages used in bilingual education remains limited to the five most widely spoken, but this covers the most used languages (UNESCO 2011). However, there is limited effort by the government to provide alternative basic education or any other adaptations to the education available to make it more relevant to the needs of minority and indigenous communities.

parliament and may identify themselves as Khmer-Islam (Palmieri 2010). There is very little information available about the access of the Vietnamese population to education and they are not mentioned in any national policy documents although the group remain highly marginalized.

${ }^{8}$ The government argues that written forms of the languages of many minority groups were lost during the time of the Khmer Rouge. There does not seem to be any option to develop scripts based on the family of the language concerned. 


\subsection{Ethiopia}

Table 4 sets out the timeline and major developments for Ethiopia.

Table 4: Ethiopia timeline

\begin{tabular}{|c|c|}
\hline Year & Development \\
\hline 1994 & $\begin{array}{l}\text { Education and Training Policy-identified constraints of access, equity, efficiency, and } \\
\text { relevance/quality and introduces free primary education. The policy also made primary } \\
\text { education in 'nationality languages' compulsory, with English as the language of instruction in } \\
\text { secondary school. }\end{array}$ \\
\hline 1995 & $\begin{array}{l}\text { Ruling Ethiopian People's Revolutionary Democratic Front (EPRDF) government-constitution } \\
\text { established the federal structure of Ethiopia and created nine semi-autonomous ethnically } \\
\text { based regions and two chartered cities. }\end{array}$ \\
\hline \multirow[t]{2}{*}{1997} & $\begin{array}{l}\text { First Education Sector Development Programme (ESDP) established and set education as a } \\
\text { national priority. }\end{array}$ \\
\hline & Second ESDP called for increased community and NGO participation in the education sector. \\
\hline 2000 & $\begin{array}{l}\text { Series of national learning assessments were launched to improve data around quality of } \\
\text { education. }\end{array}$ \\
\hline 2002 & $\begin{array}{l}\text { Launch of first poverty reduction strategy paper (PRSP) building on the existing poverty } \\
\text { reduction framework. }\end{array}$ \\
\hline 2005 & $\begin{array}{l}\text { ESDP III and the initiation of the Special Support Programme for Indigenous and Pastoralist } \\
\text { Communities. } \\
\text { Drafting of the second PRSP, Plan for Accelerated and Sustained Development to End } \\
\text { Poverty). Significant emphasis on education-education goals were set to produce good } \\
\text { citizens, expand access to UPE, develop the workforce, and build capacity in the education } \\
\text { system. } \\
\text { Productive Safety Net Programme introduced with aims to help the chronically poor resist } \\
\text { shocks, create assets, and become food self-sufficient. } \\
\text { Competitive elections were strongly disputed resulting in violent protests. }\end{array}$ \\
\hline 2007 & $\begin{array}{l}\text { General Education Quality Improvement Programme is adopted focusing on teacher } \\
\text { development, curriculum development, management capacity building, physically improving } \\
\text { schools, and school grants. }\end{array}$ \\
\hline 2010 & $\begin{array}{l}\text { ESDP IV covers the period } 2010-15 \text {, focused on increasing access and quality of basic, } \\
\text { secondary, and higher education, and developing technical and vocational education and } \\
\text { training. } \\
\text { Early Childhood Care and Education Framework policy developed to provide services to } \\
\text { prepare children and parents for the transition to school } \\
\text { (EPRDF) wins election. }\end{array}$ \\
\hline 2015 & $\begin{array}{l}\text { Ruling EPRDF wins election, widely considered not to be free and fair with a campaign } \\
\text { focused on economic growth. Opposition parties express concerns about teachers' salaries, } \\
\text { the quality of school buildings and laws that favour teachers who support the ruling party, } \\
\text { particularly in higher education. }\end{array}$ \\
\hline
\end{tabular}

Source: Authors' illustration.

Access to education in Ethiopia has increased rapidly over the last ten years, along with sharp increases in the number of teachers and schools. Gender parity in primary education has also risen sharply from a gender parity index of 0.66 in 2000 to 0.92 in 2014 (World Bank 2016a).

The Government of Ethiopia has a very strong commitment to education and sees the development of education as a fundamental part of the national development strategy (Lenhardt et al. 2015). Education sector budget allocations reached 23 per cent of total government expenditures and 5 per cent of gross domestic product (GDP) in 2010. Improved learning outcomes are seen as important to ensure that young people have the skills and knowledge needed for employment in the global economy (UNESCO 2015a) and are supported by the development of an Early Childhood Education Programme to improve children's readiness for school.

Overall efforts towards quality improvement are supported by the World Bank-backed General Education Quality Improvement Programme, the second phase of which commenced in 2014. 
This programme is focused on education system development, textbook distribution, and support including pre-service and in-service teacher training and English language support.

Disparities between the Somali and Afar regions and between the poorest quintile and highest wealth quintiles remain significant. However, the pace of change has in many cases been most rapid among these disadvantaged groups, particularly since 2005. The number of children out of school in the Somali region has decreased by 46 per cent between 2005 and 2011 compared with a 32 per cent improvement in the national average over the same period. In Afar, the number of children out of school increased from 79 per cent to 84 per cent between 2000 and 2005 and then decreased to 46 per cent according to the 2011 DHS (UNESCO 2016)

Education in national languages at primary school level is considered a right in Ethiopia and different languages of instruction are offered in all of the regions-for example, in Gambella Grades 1-4 are taught in Nuer, Anguak, or Meshenger before switching to English (Vujcich 2013).

Studies on the impact of mother-tongue teaching in Ethiopia have shown increases in the engagement and relevance of learning in targeted communities. Analysis of the 2007 National Learning Assessment found that learning in mother tongue is associated with improved achievement scores (Heugh et al. 2007) and Young Lives Research have shown that mother-tongue learning has enabled students to relate what they have learned to their environment and to understand it easily (Vujcich 2013). Mother-language teaching is the norm across the country, and the policy has been gradually strengthened and invested in since 1994. Grades 1-4 are taught in mother tongue with English and Amharic as subjects, then the switch to being taught in English and Amharic happens between grades 5 and 9.

Since 2005 the Government of Ethiopia has made large strides in increasing access to education in the pastoral Afar and Somali regions, both of which had shown slow progress between 2000 and 2005. In 2005, the government initiated a special support programme tailored for pastoralist and indigenous communities through the introduction of alternative basic education (ABE), mobile schools, and para-boarding schools and hostels. The policy includes construction of lowcost village schools to provide ABE in areas where communities are settled permanently for at least eight consecutive months. There is a flexible learning policy which allows the community to decide the time of learning and the teaching environment, and mother tongue is the language of instruction. Mobile schools have been developed for communities that are mobile for more than four months a year, providing flexible materials and on-site schools in short-stay areas and limited provision of para-boarding schools and hostels, designed with community input (UNESCO 2015a).

Between 2005 and 2011 the rate of children out of school decreased from 84 per cent to 46 per cent in the Afar region, while the primary school completion rate increased from 13 per cent to 28 per cent. In the Somali region, the rate of children out of school fell from 85 per cent to 39 per cent and the primary school completion rate rose from 9 per cent to 25 per cent (UNESCO 2016).

Other poverty reduction measures taken by the Government of Ethiopia have also had positive impacts on reducing inequalities in education, most notably the Productive Safety Net Programme (PSNP) which targets the household as a whole and is not designed with specific child welfare goals in mind. Research has consistently found positive impacts on school attendance and retention for poor rural children in households with access to the programme. For example, Woldehanna (2009) uses data from the Young Lives longitudinal study to show that the programme is associated with increased time spent on studying among rural girls and on the highest grade completed by both boys and girls. Tafere and Woldehanna (2012) find an associated increase in the time children spend in school. Debela and Holden (2014) find an increase in the 
education level of children in participant households and 44 per cent of respondent households reported being able to send their children to school due to the PSNP.

\subsection{Ghana}

Table 5 sets out the timeline and major developments for Ghana.

Table 5: Ghana timeline

\begin{tabular}{ll}
\hline Year & Development \\
\hline 1961 & $\begin{array}{l}\text { Education Act provided free compulsory education and the Nkrumah administration provided } \\
\text { free compulsory primary education through the act, complemented by expanded teacher } \\
\text { training, provision of textbooks, and other inputs. }\end{array}$ \\
\hline 1987 & $\begin{array}{l}\text { Major educational reforms culminated in the reduction of pre-tertiary education from } 17 \text { to } 12 \\
\text { years of age and the introduction of measures to improve access, equity, and quality at all } \\
\text { levels of the educational system. }\end{array}$ \\
\hline 1992 & $\begin{array}{l}\text { Constitution emphasized equality of access to education. It provides for free, Compulsory and } \\
\text { Universal Basic Education (fCUBE) and enjoins the state to make higher education } \\
\text { progressively accessible to all (Article 25). }\end{array}$ \\
\hline Expanding access to education was a key feature of education policies under President \\
& $\begin{array}{l}\text { Rawlings' National Democratic Congress administration's Vision 2020. } \\
\text { Ghana Poverty Reduction Strategy (GPRS) l-established objectives of enhanced access to } \\
\text { basic education including: improvements in the quality of basic education; rehabilitation or }\end{array}$ \\
& $\begin{array}{l}\text { construction of primary school classrooms; development of one model senior secondary } \\
\text { school with libraries and science laboratories in each of the 110 districts in Ghana, and } \\
\text { implementation of teacher retention schemes. }\end{array}$ \\
\hline 2005 & Introduction of education capitation grants and school feeding programme. \\
\hline $2006-09$ & Ghana Poverty Reduction Strategy II. \\
\hline 2008 & Complementary Education System. \\
\hline
\end{tabular}

Source: Authors' illustration.

While the pattern of poverty in Ghana persists along regional lines with the South reporting significantly lower poverty incidence than the North, there is evidence of reducing educational inequality between the two regions. The context is one of growth and poverty reduction, but with regional differences. In recent years, Ghana has experienced steadily increasing growth of over 7 per cent per year since 2005, and it attained middle-income country status in 2010. Poverty has dropped from 72.9 per cent in 2006 to 44.4 per cent in 2013 (UNICEF 2016). Andy McKay, stressed that 'of great concern is Northern region which saw its high level of poverty fall only marginally from 55.7 per cent to 50.4 per cent' (Laary 2016).

The government has recognized inequality as a policy concern in its education programmes even though financial outlays have not always matched rhetoric. The introduction of the Ghana Poverty Reduction Strategies (first in 2000 and then in 2006) channelled international funds towards government-stated priorities which included improving access to education in the North. Successful national policies included the abolition of school fees, implementation of a school feeding programme, as well as investment in school infrastructure, and for the most deprived districts, many of which are in North, the availability of a complementary education system (CBE) - see Box 1. Enrolment figures for both males and females have improved in the northern areas and the disparity in educational access between the top and bottom income quintiles has grown smaller. 
Non-state providers have been delivering CBE to out-of-school 8- to 14-year-old children in northern Ghana for over 15 years, with support from donor partners such as the Danish International Development Agency, United States Agency for International Development, United Nations International Children's Emergency Fund (UNICEF), and the UK Department for International Development, under the banner of 'School for Life'. After completing a nine-month CBE programme, children acquire sufficient numeracy and literacy to be able to enter primary school at either class three or four. These providers of CBE have delivered consistently strong results, based on their innovative approach to pedagogy, the use of children's mother tongue, and a programme that is adapted to the needs of communities where out-of-school children reside.

Source: Government of Ghana (2016).

Despite spatial inequality in poverty reduction gains, there is an indication that the gap in school enrolment between the poorest and richest in education is narrowing. The net enrolment rate in Ghana shows improvement only in the North between 1998 and 2003 (Shepherd et al 2006). While the net attendance rate ${ }^{9}$ remained the lowest in the rural savannah, ${ }^{10}$ the largest increases in net attendance also occurred in this area-15 per cent for girls and 12 per cent for boys-between 2005/06 and 2012/13 (Ghana Statistical Service 2014). The disparity between the rural savannah and the national average number of years of schooling narrowed from a ratio of 0.43 to 0.51 by 2006 (Appiah-Kubi 2003; World Bank 2006). Overall, while the gap is diminishing, however, children in the Northern Region are still four times more likely to be out of school than those in Ashanti Region.

Gender parity has been achieved at the national aggregate level though gender gaps continue to exist in Northern Region. Meanwhile ethnic disparities persist: children from the Gurma group are 2.5 times more likely to be out of school than those from the majority Akan ethnic group, (UNICEF 2012). ${ }^{11}$

Findings show that females in the northern half of the country are particularly disadvantaged. The percentage of females who have never been to school is 59 per cent in Northern Region, as compared with only 14 per cent of females in Greater Accra. Higher proportions of males in the three northern regions have never been to school (Northern, 44 per cent; Upper West, 41 per cent; and Upper East, 32 per cent), compared with 20 per cent or less of males in other regions.

The government has consistently remarked on inequality in education as a policy focus area. Ghana is characterized by an inclusive national discourse on education that emphasizes equal access to schooling as evinced by the Education Act of 1961, the Constitution of 1992, and focus on educational access by governments in 1987 and 1993/95.

\footnotetext{
${ }^{9}$ According to the Ghana Living Standards Survey (Ghana Statistical Service 2014) 'Net attendance rates of children at Primary, JHS and SHS is the number of children of official schooling age (as defined by Ghana Education Service) who are attending Primary, JHS and SHS as a percentage of the total children of the official school age population'.

${ }^{10}$ Rural savannah refers to the agro-ecological zones of the three northern regions and parts of Volta and Brong Ahafo regions, with a combined population of 4.7 million people (Ghana Statistical Service 2014).

11 'The needs of disadvantaged groups including people with disabilities, girls, and extremely poor children, are often not adequately addressed by education sector financing. For instance, the special education division is allocated less than 1 per cent of total education budget, but rarely receives even this. The girls' education unit and early childhood units also receive very little financing, often resulting in the failure to properly implement their programmes' (UNICEF 2012).
} 
Financial outlays to further the objective of equality in education have varied across the years. An analysis of budget commitments and expenditures covering the period between 1997 and 2008 has suggested 'that while budgetary allocations were somewhat informed by equity considerations, actual expenditure distribution was not' (Abdulai and Hickey 2014). In 1997, the government admitted that 'the least expenditures were made in the Northern, Upper West and Upper East regions with the share of Upper East region being only 0.8 per cent' (Government of Ghana 1998: 12-13). Overall government expenditure on education as a percentage of GDP increased from 1.4 per cent in 1983 to 8.1 per cent in 2011 (World Bank 2015). It subsequently declined to 5.9 per cent in 2013 (World Bank 2015).

Since the year 2000, the government has rolled out a number of educational reform efforts under the GPRS I and II which have highlighted regional inequality as a key feature of poverty in Ghana. In 2006 the World Bank noted that funds channelled by international donors under the GPRS had been able to reach the northern areas to effect improvements in educational infrastructure. For example, in 2004 the Organization of the Petroleum Exporting Countries (OPEC) Fund concentrated on providing basic schools in the three northern regions (World Bank 2006; OPEC 2004). The share of rehabilitation/construction of primary classrooms in 'the three Northern regions increased from 20 per cent in 2002 to 30 per cent in 2004; 420 of 685 (61.3 per cent) of three-unit classrooms constructed were located in the three Northern regions; 96 (21.8 per cent) of the 440 of the six-unit classroom blocks under construction nationwide are in the three deprived Northern regions' (World Bank 2006).

Apart from investment in school infrastructure, the removal of school fees for parents has also improved enrolment in the northern areas of Ghana. In 2005, the Government of Ghana introduced a capitation grant, whereby schools receive a fixed amount of funds based on the number of pupils enrolled, at approximately US $\$ 6$ per pupil (replacing the charges schools imposed on parents for school-based activities). This started in deprived districts before being spread nationwide. According to Ghana's Education Management Information System data, after capitation grants had been introduced, basic school enrolment increased by an estimated 17 per cent (Government of Ghana 2007) ${ }^{12}$. Using the same data, Maikish and Gershberg (2008) reported that capitation grants had a particularly positive effect on enrolments in deprived areas, suggesting that fees had a been a barrier to access. Regional-level data suggest that the grant may have had greater impact on some of the poorest regions in the country, namely the Upper East, Upper West, and Northern Region (Thompson and Casely-Hayford 2008). At the primary level the enrolment of girls (18.1 per cent) rose more than that of boys (15.3 per cent). Additionally, children returned to school and also remained in school (UNICEF 2012).

High numbers of out-of-school children in the North have been analysed as a consequence of seasonal work children carry out during harvest season to increase family earnings. A Complementary Basic Education Policy in 2008 drafted by the Ministry of Education, in recognition of this seasonal calendar, promoted flexible school models targeted towards out-ofschool children between the ages of 8 and 14. The policy has not been implemented on any large scale and continues to be limited to the three northern regions (UNICEF 2012). Under the programme, out-of-school children (from 8 to 15 years of age) receive classes in their mother language. The programme aims to provide these children with basic literacy in nine months. To date, the programme has helped more than 120,000 children in northern Ghana obtain basic education. A study by the Ministry of Education has recommended that students from the complementary system moving into the formal education system had the effect of raising the gross

\footnotetext{
12 This was followed by a decline in education quality as the provision of additional teachers, facilities, and logistics lagged behind the capitation grant (UNICEF 2012).
} 
enrolment rate by 2 to 3 per cent in the Northern Region between the years of 1995 and 2005 (Government of Ghana 2006).

A policy framework for complementary basic education was developed in 2013, and although it was endorsed by the Minister on 17 December 2014, it has yet to be implemented. The Government noted in the November 2014 budget statement, that it aims to 'expand the Programme to cover 420,000 out-of-school children currently not covered'.

In Ghana, language policy has switched frequently between two systems. In some years the English-only medium classrooms (1957-66; 2002-05) were allowed and in other years, a Ghanaian language was allowed for the first three years of schooling (1967-69; 1974-2002) (Owu-Ewie 2006). Education in the local language has been a popular mandate for the right-of-centre political parties (most recently the New Patriotic Party). Eleven indigenous languages were pre-eminent in classrooms in the years when Ghanaian languages were used e.g. Akan (Fante and Twi), Nzema, Ga, Ga-Adangbe, Ewe, Gonja, Kasem, Dagbani, and Dagaare. Secondary and tertiary education in the country takes place in English (Sherris et al. 2012). In 2007, the country introduced bilingual education through the National Literacy Acceleration Programme (NALAP). Under this programme, children learn to read in their mother tongue (in the 11 languages mentioned earlier) as well as learning to speak English (Leherr 2009).

The Ghana School Feeding Programme in 2005 directly impacted school enrolment in the North of the country. The World Food Programme's (WFP) country programme evaluation and evaluations of the Feeding Programme, infers school feeding to be very effective in raising enrolments in areas suffering from food insecurity (Brinkman et al. 2010). The WFP and the government of Ghana have been funding take-home rations, over the last ten years, across the three northern regions of the country, in order to incentivize parents to send and keep girl children in schools. In these areas girls' enrolment in assisted schools grew by 42,000 from 9,000, and retention rates doubled to 99 per cent during the 2006/2007 academic year (Brinkman et al. 2010; UNICEF 2012).

\subsection{Nigeria}

Table 6 sets out the timeline and major developments for Nigeria.

Table 6: Nigeria timeline

\begin{tabular}{ll}
\hline Year & Development \\
\hline 1976 & Free UPE. \\
\hline 1977 & $\begin{array}{l}\text { National Policy on Education: first published in } 1977 \text { and revised in 1981, 1995, 1998, } \\
\text { 2004, and 2006. }\end{array}$ \\
\hline $\begin{array}{l}\text { Universal Basic Education UBE): one major distinguishing feature of the UBE from UPE } \\
\text { was the extension of the scheme to three years post-primary, while making primary and } \\
\text { junior secondary education free, universal, and compulsory (although the federal } \\
\text { government never implemented compulsory education due to political factors). }\end{array}$ \\
$\begin{array}{l}\text { Universal Basic Education Commission Law enacted stating 'Every Government in Nigeria } \\
\text { shall provide free, compulsory and universal basic education for every child of primary and } \\
\text { junior secondary age'. }\end{array}$ \\
\hline
\end{tabular}

Source: Authors' illustration.

Poverty incidence in Nigeria is higher in the North than it is in the South and educational inequality follows the same pattern. Ethnic and religious identities overlay spatial inequalities to reinforce them. The North is largely Muslim while the South is predominantly Christian and the former lags behind the Christian community in educational outcomes. Despite commitments to providing equal access to education in the country, the Nigerian government has not explicitly made the reduction of inequality in education a policy focus. This is compounded by the absence of accurate 
data on schooling figures and an overall reduction in educational expenditures throughout the country since the 1980s. The latter is variously attributed to: the reduction in oil revenues when oil prices declined at that time; IMF/World Bank-inspired austerity; and the preference of military regimes for military expenditure. Further the sector is also mismanaged.

In Nigeria, inequality in education persists along multiple, overlapping dimensions: regional, religious, income, and ethnicity:

- The southern regions in the country are more advantaged than the northern areas. In his study on attendance rates in Nigeria, Lincove (2009) found that rates were significantly lower in the northern regions than in the southern regions; the Northeast and Northwest regions reported over 90 per cent of out-of-school children. Out of the 19 northern states, only two states (i.e. Kwara state and Kogi state) have average attainment above the national average while all of the southern states are above the national average (Umar et al. 2014).

- Nigeria's Christian population is more advantaged than the country's Muslim population. The latter are disadvantaged at an early age and lag behind over time, falling behind Christians by more than four years of education by the age of 24 (Dev et al. 2015).

- There is high inequality in primary school completion rates across income quintiles. In 2008, 75 per cent of the poorest children had been unable to finish primary school, compared with just one-fifth of the richest (UNESCO 2015c). The 2006-10 national educational statistics from the Federal Ministry of Education indicate a decline in gross enrolment in public primary schools by around 12 per cent in 2010. By contrast, private primary school enrolment, (accounting for 10 per cent of total enrolment) increased during the same period (Wetheridge et al. 2012).

- Nigeria has over 400 ethnic groups and there is high inequality in the years of education attained by different groups. For instance, Yoruba, Niger-Delta, and Igbo children with ten years of education by age 24 , are more educated than the children in the Middle-Belt (eight years) and the largely northern Hausa/Fulani/Kanuri children (four years) (Raheem et al. 2014).

There is an observable relationship between the multiple dimensions of identity in Nigeria and education outcomes. Religious affiliation in the country falls along ethnic lines: Christians are more concentrated among the Igbo, the Niger-Delta, and the Middle-Belt, whereas Muslims are more concentrated among the Hausa/Fulani/Kanuri. In addition, the Northern Region of Nigeria is predominantly Muslim. In predominantly Muslim groups, children tend to invest heavily in Koranic education while there is higher investment in formal education among Christian groups. The former choose Koranic education as an alternative to formal education, even when formal education is free. Among the Hausa/Fulani/Kanuri, 23.5 per cent of children have only a Koranic education, in stark contrast to the Igbo (0.1 per cent), the Yoruba (0.4 per cent), the Niger-Delta (0.4 per cent), and the Middle-Belt (2.7 per cent). Among the Yoruba, roughly 40 per cent are Muslim, so it is apparent that region and wealth likely play a significant role in these choices (Dev et al. 2015).

Christian missionaries first introduced formal Western education in Nigeria in the south of the country during the colonial era. Consequently, coastal areas in southern Nigeria and other parts of West Africa with more missionary settlements tended to have greater access to education than the more remote northern areas (Aguolu 1979). 
Government policy documents have not recognized the need to address inequality among regions and tribes as a specific goal of the education policy. Overall trends in government expenditure have been similar and discouraging. Four years after the government launched the UPE, federal state public expenditure on education (as a share of total expenditures) rose to 24.7 per cent compared to 16.4 per cent in 1975 prior to the introduction of the UPE scheme (Onwuameze 2013). Since then, despite commitments to provision of free and universal education, government expenditures on education have been declining over the last two decades. The Federal Ministry of Education's budget share dropped from 8.6 per cent of the national budget in 2006 to 8.35 per cent in 2008, 5.3 per cent in 2010, and 3.1 per cent in 2012 (Wetheridge et al. 2012).

The state response to Boko Haram has largely been one of increasing security forces in and around schools and carrying out security force operations in Koranic schools (Human Rights Watch 2016). In 2015, UNICEF started helping the government integrate a broader curriculum into Koranic schools in the country (Moser 2015).

In terms of regional effort, in 2002 'education expenditures were equal to 15 per cent of total federal expenditures and 21 per cent, 27 per cent and 29 per cent of the total expenditures of the Northern, Eastern, and Western Regional Governments respectively' (Hinchliffe 2002). Even today, with Boko Haram partly a product of the absence of educational and other progress made in parts of the North, the developmental response to conflict seems completely overshadowed by the security response.

\subsection{Peru}

Table 7 sets out the timeline and major developments for Peru.

Table 7: Peru timeline

\begin{tabular}{ll}
\hline Year & Development \\
\hline $1968-75$ & $\begin{array}{l}\text { General Velasco Alvarado puts in place a decentralized educational system where } \\
\text { indigenous groups organize and run the institutions. } \\
\text { Promulgates a National Policy of Bilingual Education. } \\
\text { A law to make Quechua an official language is passed. }\end{array}$ \\
\hline 1979 & Quechua becomes an official language in the Constitution. \\
\hline 1987 & The Department of Bilingual Education is re-established and a Bilingual Intercultural \\
& Education Policy comes into force. \\
\hline 1993 & $\begin{array}{l}\text { The new Constitution recognizes the ethnic and cultural plurality of the country and gives } \\
\text { all people the right to use their native language. } \\
\text { The National Office for Bilingual Education is dissolved due to paucity of funds. Pressure } \\
\text { from international and domestic actors results in the unit being re-opened as a smaller } \\
\text { entity within the National Office of Elementary Education. } \\
\text { Wawa Wasi National Programme implemented to promote the optimal development of } \\
\text { children aged 6 to 48 months in impoverished areas. }\end{array}$ \\
\hline 1993 & $\begin{array}{l}\text { General Education Law (Ley General de Educación) set a goal for compulsory basic } \\
\text { education. }\end{array}$ \\
\hline 2003 & $\begin{array}{l}\text { JUNTOS conditional cash transfer programme commences in Peru that provides a lump } \\
\text { sum transfer to poor families if they meet certain eligibility criteria one of which is school } \\
\text { attendance for at least } 85 \text { per cent of the school year. }\end{array}$ \\
\hline
\end{tabular}

Source: Authors' illustration.

Regional income inequality overlaps with educational inequality in Peru, with indigenous populations living in rural areas at a disadvantage in both income and education and white/mestizo populations concentrated in urban areas at a relative advantage. Language is a major factor in influencing the outcomes of education in Peru with sizable achievement gaps between Spanishspeaking groups and groups speaking indigenous and minority languages as their mother tongue. The government has made rhetorical commitments to the idea of bilingual education in the early 
years of education, but implementation has been poor, resulting in increased inequality despite an overall increase in the education budget as a percentage of the GDP (increasing from 2.7 per cent in 2011 to 3.7 per cent in 2014) (World Bank 2015).

Extreme poverty remains highly rural and although recent growth in the country has caused a decline in the Gini Index (from 0.49 in 2004 to 0.44 in 2014), the contribution to the decline has come from urban areas. In rural areas the Gini Index decreased by just 3 points between 2004 and 2013 (from 0.44 to 0.41) (World Bank 2016b). The population composition of the rural and urban areas is also distinct: the white/mestizo population is found mostly in Lima and other large cities. The indigenous population is concentrated mostly in rural areas.

The pattern of educational inequality matches income inequality in Peru. In 2012, Peru's standard Programme for International Student Assessment (PISA) test scores (a standardized test used to compare educational quality across and within countries) ranked last among all 65 countries in both maths and reading (Salazar 2011). In 2009, only 12 per cent of students in rural areas were found to have passed the reading comprehension test. This was in stark opposition to the 29 per cent that passed in urban areas (Muelle 2016). In maths, educational outcomes were similar with only 7 per cent of students in the countryside passing the test and 17 per cent in cities. A Peruvian indigenous adult spends a mean number of 6.4 years in school compared to the average nonindigenous adult's 8.7 years (Snyder 2008). Considerable gaps exist not only in pupils' access, but also their transition from one grade to the next and by socio-economic group, ethnicity, and location (Murray 2012).

There is some evidence to suggest that this educational inequality is driven by linguistic barriers and exclusion of the indigenous population from the education system. Although indigenous people account for an estimated 45 per cent of Peru's total population, indigenous language is considered to be of low prestige, and the Spanish language has been promoted by the educational system as well as in official circles. Quechua was made one of the official languages only in 1979 and its use in schooling systems was limited to six years of primary education. ${ }^{13}$

By 2012, around 1,200 schools had implemented bilingual education in their school programmes. Despite commitment in theory, practically, the system has struggled to provide actual bilingual education. Constraints range from the lack of bilingual educational materials in schools, lack of teachers with adequate language skills, and the rejection of bilingual education by indigenous parents borne of the fear that it would limit their children's learning and fluency in Spanish.

A Young Lives longitudinal study of childhood poverty in Peru tracing the lives of 3,000 children over 15 years (2002-17) found that language was a key driver of achievement gaps for children in Peru (Murray 2012). According to the study, 'children with mothers who have no secondary education and/or speak an indigenous language are less likely to attend pre-school and have poorer abilities at the age of $5 .{ }^{14}$ These same children are more likely to attend primary schools with poor

\footnotetext{
13 'The full extent of Peru's linguistic diversity is still a debate. It is argued that there are 59 languages including Spanish, which belong to 11 or 12 distinct linguistic groups. Quechua and Aymara are the most commonly spoken languages within indigenous groups' (Freeland 1996).

${ }^{14}$ There is a range of programmes implemented. Formal early education consists of Centros de Educación Inicial (CEIs) for children aged 3-5 years. CEIs have been supplemented by non-formal community-based programmes called Programas no Escolarizados de Educación Inicial (PRONOEIs). There is one study that states that 'figures show that overall levels of early childhood provision are high in Peru' (indeed, the percentage of the age group accessing pre-school is amongst the highest in the region), but the data source it cites is no longer online. See: Woodhead et al. (2009).
} 
resources, to be behind their normative grade and to have poorer achievement results at the age of 8' (Murray 2012:8).

Access to schooling infrastructure is similarly unequal between urban and rural areas and hence between the white and indigenous populations. As of 2011, there were 44,480 educational institutions in rural areas of Peru, including 22,000 primary schools (Salazar 2011). In one-fourth of cases, students' homes are far from their schools and road and transport infrastructure is limited. For this reason, children from rural areas join the school system when they are old enough to walk long distances. Students tend to live away in order to attend school and return to their homes in rural areas only at weekends or during holidays. One study found that: 'In 2006, only 13 per cent of rural villages and towns had secondary schools. In rural villages in the Amazon district of Datem de Marañón in northern Peru, teachers often have 70 students in their one-room schoolhouses and travel two or three days to get to their jobs' (Salazar 2011).

These constraints were too great to be addressed by Peru's conditional cash transfer programme, JUNTOS, which commenced in 2005. With respect to education outcomes, one analysis of the programme's impact suggests that JUNTOS had limited impacts on school registration and attendance. Still, the transfer constitutes a moderate 15 per cent of the average household monthly consumption and it appears the transfer is more crucial at points where the opportunity costs are more binding, namely entering and finishing primary school (Perova and Vakis 2009).

An evaluation of the government cash transfer programme JUNTOS found that it had a small impact on school registration and no effect on overall school attendance. Results suggested that the JUNTOS impacts mattered the most at points when children entered primary school and at points when they moved from primary to secondary.

Peru's Wawa Wasi early childhood programme targets disadvantaged groups (Cueto et al. 2009). An evaluation of the program has shown that there is little difference in terms of fine motor, gross motor and language skills of pre-school children who have spent at least six months at a Wawa Wasi and those who have stayed at home, perhaps because the centres put little emphasis on learning. However, community members and local programme staff perceive Wawa Wasi centres as day centres where children are safe and well-nourished while mothers are at work. It is unlikely that a child whose mother does not work will attend a Wawa Wasi (Cueto et al. 2009). 


\subsection{Uganda}

Table 8 sets out the timeline and major developments for Uganda.

Table 8: Uganda timeline

\begin{tabular}{|c|c|}
\hline Year & Development \\
\hline 1989 & $\begin{array}{l}\text { Education Policy Review Commission Report-foundation for the reform of the education } \\
\text { sector in Uganda put forward a ten-point programme for reform based on access, equity, and } \\
\text { quality. }\end{array}$ \\
\hline 1992 & $\begin{array}{l}\text { Government White Paper on Education-restates many of these goals-national unity, } \\
\text { scientific, technician, and cultural knowledge needed to promote development and build the } \\
\text { economy. }\end{array}$ \\
\hline 1995 & $\begin{array}{l}\text { Constitution-states the right of every Ugandan to education and notes the government's } \\
\text { responsibility to provide free UPE. }\end{array}$ \\
\hline 1996 & First competitive election-Museveni becomes president. \\
\hline 1997 & Introduction of UPE; EAP Poverty Eradiation Plan Adopted. \\
\hline 1998 & $\begin{array}{l}\text { Introduction of the Education Sector Investment Plan, sets out how the Government and } \\
\text { donors plan to achieve UPE. }\end{array}$ \\
\hline 2001 & First multi-party competitive elections are held. \\
\hline 2004 & $\begin{array}{l}\text { Education Sector Strategic Plan Adopted-and then amended in } 2007 \text { after the elections. } \\
\text { Marks the government's shift from a focus on UPE towards secondary education and technical } \\
\text { and vocational training. }\end{array}$ \\
\hline 2006 & $\begin{array}{l}\text { Introduction of universal secondary education (USE). } \\
\text { Government and Lord's Resistance Army sign a truce aiming to end the conflict and beginning } \\
\text { peace negotiations. }\end{array}$ \\
\hline 2007 & $\begin{array}{l}\text { Peace, Recovery and Development Strategy launched. Aims to provide continuous education } \\
\text { for internally displaced persons. } \\
\text { Thematic Curriculum is introduced-aimed to improve the relevance of education to local } \\
\text { communities and focuses on literacy, numeracy, and life skills and commits to mother-tongue } \\
\text { learning in early years. }\end{array}$ \\
\hline 2008 & $\begin{array}{l}\text { Education Act and Business, Technical, Vocational Education and Training begins the } \\
\text { formalization of the vocational education system with the establishment of standard } \\
\text { qualifications. } \\
\text { Government and Lords Resistance Army sign what should have been a permanent cease-fire } \\
\text { agreement. }\end{array}$ \\
\hline 000 & in Fducation introduced \\
\hline
\end{tabular}

Source: Authors' illustration.

Uganda introduced UPE in 1997 with a 'Big Bang' approach which eliminated fees for primary education - the number of children enrolled in primary school rose from 3.4 million in 1996/97 to 5.3 million in 1997/98, and to 6.9 million in 2001 (Murphy et al. 2002). Initially this universal policy was successful in reducing disparities in access to primary education between rural and urban areas, by gender, and across wealth quintiles. There was also significant progress in the conflictaffected Northern Region-where the number of out-of-school children had fallen from 45 per cent in 1995 to 10 per cent in 2011 (Higgins 2009; UNESCO 2016;).

Since 2000, progress seems to have stalled and in some cases inequalities have increased-most notably the proportions of out-of-school children in the poorest wealth quintiles and in the Karamoja region. Disparities by gender become more evident as students move up the education system and girls face specific barriers to quality education, discussed in more detail below. The 
levels of completion at both lower- and upper-secondary school remain very low on average and there are also major concerns around the quality of education-with persistently low literacy and numeracy rates (UNESCO 2016). Despite the increase in the number of children attending primary school, the number passing the national primary leaving exam has only increased marginally (Hedger et al. 2010). In 2006, USE was introduced with the aim of providing options for the large number of children graduating from primary school, although vocational training options have been described as 'ineffective' (Danish Trade Union Council for International Development Cooperation 2015).

The Government of Uganda is committed to education as part of the national poverty reduction strategy and has described the need for 'knowledge-based, informed and skilled' citizens of Uganda (Government of Uganda 2010), commitments that echo those made in the 1989 Education Policy Review Commission Report and 1992 Government White Paper on Education. The 2004-15 Education Sector Strategic Plan, amended following the 2006 elections, which introduced USE, is focused on achieving increased relevance and quality as well as improving the quality and efficiency of service delivery. This is predominantly a growth rather than an equity agenda.

Efficiency concerns about budget leakage between central government and schools within schools, as well as inefficient allocation of resources within schools have been somewhat addressed with the Public Expenditure Tracking Surveys reducing leakages of primary school funds from 74 per cent to 20 per cent (Hedger 2010; Kingdon et al. 2014).

Spending on education, however, has not kept pace with the overall budget over time and has not been consistent - there have been large increases in the years around the introduction of universal primary and secondary education, but overall the share of the national budget spent on education has decreased-falling from 24 per cent in 1997/1998 to 17 per cent in 2015. The 2015 national Education for All review puts this down to competition with other sectors such as energy and infrastructure.

The government also seems reluctant to introduce any programmes to assist the poorest quintiles with the additional costs of school_-such as uniforms or transportation-stating that the 2008 Education Act compels parents to provide these things (UNESCO 2015b; Bantebya et al. 2013). Universal primary and secondary education have both been introduced by President Museveni during competitive election cycles as the policies enjoy strong popular support, suggesting an element of opportunism more suggestive of a need to keep the current leadership in power than a commitment to education but also that elections can boost education spending (Mbabazi et al. 2013; Stasavage 2005). ${ }^{15}$

Longstanding disparities between North and North East Uganda and the rest of the country are reflected both in education data and relatively modest declines in poverty (Higgins 2009; Ekaju 2011; McCormac and Benjamin 2008). The North and Karamoja regions that make up this area have both been affected by long-running conflict with the Lords Resistance Army, conflict among pastoralist groups, and environmental degradation (Ekaju 2011). In recent years, the North as a whole appears to have made progress catching up with the rest of Uganda in education indicators. However, the Karamoja region lags far behind.

There has been acknowledgement from the Government of Uganda of the need for targeted action to reduce inequality in these regions - in 2007 the Peace, Recovery and Development Strategy aimed to provide education in an internally displaced persons camp and development and

\footnotetext{
${ }^{15}$ There seems to be a gap in recent research from the region, perhaps due to ongoing instability.
} 
reconstruction programmes are in place for both regions (Ekaju 2011). The provision of education infrastructure appears to be the focus of these programmes through monies received from school facilities grants. Other disparities have not been tackled: for example, Higgins (2009) suggests that the system which standardizes teachers' wages across Uganda means that there is no incentive for teachers to go and work in difficult areas.

DHS data on education in Karamoja only became available with the 2011 DHS, which found that out-of-school children had reached 43 per cent and that, at 50 per cent, out-of-school adolescents was also far behind other regions. There are longstanding small-scale efforts to provide education through the Alternative Basic Education for Karamoja programme, which began with a pilot project in 1996 and uses Nakarimojong as the language of instruction; a tailored curriculum has been developed and classes are scheduled around children's other commitments (Carr-Hill and Peart 2005). Unison MG Consulting Services (2009) note that among the remaining challenges to delivering education in Karamoja are the recruitment of local teachers, the need for mobile and stationary school buildings, and increased financial and in-kind support to parents to lessen the opportunity costs of children attending school.

Gender near-parity in primary school enrolment has been achieved primarily due to the UPE policy. However, fewer girls than boys make the transition to secondary school - the gender parity index (GPI) improved over the years 2000, 2001, and 2002 with GPI of 1.01, 1.03, and 1.04 respectively. However, in 2006 there was a decline to 1.02 and then 0.94 in 2010.

The Government of Uganda has a number of gender in education policies and even a multisectoral gender in education task force but, as Bantebya et al. (2013) point out, the implementation of these policies at the local level is often deficient and lacks funding. Government campaigns to positively change attitudes towards girls have largely been small in scale and evaluations of their impact are unavailable. Girls in Uganda continue to face constraints to their participation in education due to persistent negative gender norms which include the privileging of boys' education, unequal burdens of household work, and early marriage and pregnancy (Huntington 2008; Nordic Consulting Group 2008).

The case of Uganda illustrates that specific targeted measures are needed to redress historical imbalances in access and quality of education, but also that, without an equity-focused political discourse, this is unlikely to emerge. It also illustrates the power of enhancing access to education as an election issue, with attendant temporary rises in education expenditure; however, in the longer term, education expenditure has had to give way to other expenditures considered to support economic growth more directly.

\section{Comparative analysis}

The following section explores common features of effective anti-discrimination measures undertaken in those countries where inequalities have been observed to have decreased and compares these measures to those undertaken in countries where inequalities have remained high or decreased. The results of this comparative analysis provide insights into the political economic trajectories that have led some countries to tackle discrimination directly through legal and policy measures and some of the common ingredients that have contributed to those measures' achievements. 


\subsection{The combination of general and targeted or group-specific measures}

Firstly, then, a good long-term general education policy with a significant focus on increasing equity or reducing inequality, as well as targeted measures focused on specific groups, have been shown to be most effective when combined. General measures are important to get the necessary quality improvements in education without which an education can be of little practical value and also to create a societal and political commitment to universal access and retention. For example, the universal removal of school fees or a school feeding programme could have a particularly strong effect on enrolment in more deprived regions-as in Ghana. Targeted measures are then also needed to enable children to start learning in their mother tongues, and/or to resolve the particular constraints facing individual groups, such as the movement of pastoralists in Ethiopia.

Where inequality has reduced, targeted measures have gone alongside universal measures, and it is very difficult to disentangle the effects of one compared to the other, except where the less successful countries all had general measures but lacked the targeted or group-specific measures (with few exceptions).

Of the successful countries, Ethiopia and Ghana both had political and policy discourses centring on equity, with a view to enhancing the participation of discriminated-against groups (Ethiopia) or regions (Ghana). Cambodia had an economic growth objective for its education policies, and its post-Khmer nation building project meant that leaders were reluctant to differentiate among ethnic groups for fear of fomenting separatism. But the inter-ethnic inequalities in Cambodia remained large (larger than Ghana, though still smaller than Ethiopia, where inequalities ran highest among the successful countries). This suggests that both effective general policies (which Cambodia also had to a degree) and specific measures against inequalities and institutional discrimination are more important than an equity discourse. Interestingly, with the development of more competitive electoral politics, Cambodia has moved to a more balanced economic-human development approach to education, in which the human development outcomes are valued for themselves to a greater extent.

By comparison, Uganda has also approached education policy within a growth framework as in Cambodia, but Uganda has not developed the concern for equity across ethnic groups seen in Cambodia - a result of the growing dynamic of electoral political competition which has remained suppressed in Uganda. It is interesting to compare Cambodia's somewhat better results from within a growth-focused educational discourse. One obvious difference was the willingness to engage with minority languages in Cambodia and to develop a broader educational policy for indigenous people and later for children with disabilities. Uganda could in theory learn from this. What would propel such learning? In Cambodia, the underlying concern is with secession; in Uganda the extreme anti-developmental nature of the Lord's Resistance Army perhaps meant that a mainly security-based approach to addressing conflict was never challenged. If there was no threat factor, it would need to come from political competition, as in Cambodia, which remains stifled in Uganda.

\subsection{An inclusive political discourse}

Countries tackling inequalities head on (Ethiopia and Ghana) have constitutions that supported actions to address inequalities and inclusive political systems of different types). Constitutional processes and the construction of political systems which take account of inter-ethnic inequalities are key explanations of countries' abilities to reduce inequalities. What Ethiopia had and Ghana lacked was a public financial system which privileged deprived regions or districts. In Ethiopia, the shock of a substantial opposition vote in the 2005 elections led the ruling party to renew its 
'coalition' with the Ethiopian people and deepen its consultation and participatory processes (Vaughan 2016).

The countries where inequalities did not reduce had few or no group-specific or targeted measures, or none with much traction. By comparison with the successful countries and, surprisingly, given the inequalities and histories of discrimination and episodes of violence or civil war, neither Nigeria, Peru, nor Uganda had equity-focused discourse in education.

Uganda did make explicit commitments to equality of access to education in its 2005 Constitutional Amendment, which was part of the process of bringing its civil war to an end. However, this stopped short of mandating the government to undertake specific measures to redress inequalities (Right to Education Project n.d.a). And while equality is mentioned in the Nigerian 1999 constitution, it is much less of a focus than in other countries observed in the study (Right to Education Project n.d.b). The Peruvian 1993 constitution emphasizes choice rather than equality in education, though it does mention mother-tongue education, and there is a general commitment to equality (Right to Education Project n.d.c).

Are political systems not structured to be inclusive? This would be true of Uganda where there is a winner-takes-all system which represses the opposition and parties are not required to have membership or representation in all regions. Nigeria has had a more electorally competitive political system since the end of military rule in 1999, but only in 2015 has the opposition won. It is possible that this greater degree of competition will foster a stronger inclusion dynamic. In Peru, there has been fragile support for democracy, and significant dissatisfaction from those most excluded. According to Carrión et al. (2006) 'residents of the Southern Highland (Sierra Sur) whose parents speak a native language and who have a low-income level, exhibit a level of support for the system that is significantly inferior to the national average'.

\subsection{A 2005 watershed?}

A third factor relates to the timing of measures aimed at increasing equity. Several measures were taken in Cambodia, Ethiopia, Ghana, and Uganda around 2005-06. This was the period when a second poverty reduction strategy (PRS) was designed, based on the results from the first PRS period. In all of these countries it had become clear that certain groups had been left out.

This observation is interesting: analysts are often cynical about the effects of evidence on policymaking by comparison with the influence of elections or other processes of political regime change, crises, and other events, but this would seem to be a case where evidence on educational inequality had significant impacts across a variety of political contexts. In all of these there was, for different reasons, a focus of political discourse on inequalities between ethnic groups, even if this was submerged behind a veil of concern with national unity, as in Cambodia, where the threat of secession was taken seriously. In Uganda, the influence of the 2005 referendum on moving to multi-party politics, and the first multi-party elections in 2006 , may have been greater than the role of evidence.

This was also a period when the global exclusion discourse was imported into developing country discussions about poverty reduction, and the adoption of new measures may be an indicator of the influence of donor agencies in developing country policy development. It is possible that Nigeria's oil wealth has meant that aid has been much less influential than in the three more successful countries, which in turn deprived Nigeria of the early exposure to poverty-focused thinking (Nigeria's first PRS was developed for the 2004-07 period). This may also have limited the amount of evidence collected on such issues that was made possible by donor interest and funding elsewhere. 
In Uganda, donors were initially against UPE and USE when they were introduced as politically driven initiatives via elections. This was due to capacity problems in Uganda's education sector and the worry about the resulting declining quality of education. Later donors were more supportive of UPE but, perhaps because they were wrong footed, may have focused on assisting with capacity catching up with demand rather than equity. For example, Sector Budget Support was initially provided by many donors to help implement UPE commitments made in 1997, but donors later withdrew from these when it became clear that access was privileged over quality (Hedger et al. 2010).

Without these first two factors, there is a deadweight of history which has made it difficult to challenge inequality and associated discrimination. The regional patterns of inequality have remained stable in Nigeria, Peru, and Uganda. It requires a major initiative of the sort which requires a massive investment of political capital to overturn such stable patterns.

A final, and very education-specific policy issue, is whether inequalities among ethnic groups can be reduced without supporting education in mother tongues. It seems likely that having several years of mother-tongue education is necessary for children who do not speak the educational lingua franca. Stronger commitments on this issue were found in the inequality-reducing countries.

\section{Conclusion}

Evidence from the quantitative analysis undertaken in this study shows that efforts to tackle groupbased inequalities in human development have been mixed, with some countries experiencing a degree of success in reducing inequalities in human development between different ethnic groups while other countries have either maintained high levels of group-based inequalities or have seen inequalities in human development increase.

Although context and group-specific experiences of discrimination varies by country, certain lessons can be drawn by comparing policies adopted by countries that have seen progress in reducing inequalities to those that have seen minimal or negative change. Namely, the combination of general and targeted or group-specific measures has been shown to be a more effective means to address inequalities in education than universal measures on their own. Inclusive political discourses that directly acknowledge group-based disadvantages and which enshrine commitments to tackle those disadvantages in formal processes and legal instruments have also been shown to be an important contributing factor to the reduction of group-based inequalities in education. Beyond acknowledging these disadvantages, countries that have experienced some success in tackling group-based inequalities have engaged with policy-relevant evidence and the wider global exclusion discourse in the design of anti-discrimination measures in their national contexts.

Tackling discrimination and reducing group-based inequalities in human development is a longterm investment of resources and political will. However, the findings from this analysis have demonstrated some of the channels through which positive change can be achieved over the medium term. Further monitoring of those countries that have achieved some progress towards reducing inequalities in human development will be important to understand the long-term gains and sustainability of these anti-discrimination measures, and further analysis of other countries' experiences in tackling group-based inequalities are needed to contribute to the evidence base that other countries could draw upon when designing their own anti-discrimination measures adapted to their context. 


\section{References}

Abdulai, A.G., and S. Hickey (2014). 'Rethinking the Politics of Development in Africa? How the "Political Settlement" Shapes Resource Allocation in Ghana'. ESID Working Paper No. 38. Manchester: Effective States and Inclusive Development.

ADB (Asian Development Bank) (2002). Indigenous Peoples/Ethnic Minorities and Poverty Reduction: Cambodia. Manila: Asian Development Bank.

ADB (Asian Development Bank) (2014). Country Partnership Strategy 2014-2018: Cambodia. Manila: Asian Development Bank.

Aguolu, C.C. (1979). 'The Role of Ethnicity in Nigerian Education'. The Journal of Negro Education, 48(4): 513-29.

Appiah-Kubi, K. (2003). 'Education Inequality in Ghana: Micro Impact of Macroeconomic and Adjustment Policies (MIMAP)'. Ghana Research Report No. 001. Accra: Center for Policy Analysis.

Bantebya, G., F. Kyoheirwe Muhanguzi, and C. Watson (2013). 'Adolescent Girls and Gender Justice: Understanding Key Capability Domains in Uganda’. Country Report. London: ODI.

Brinkman, H-J., J-M. Bauer, and L. Casely-Hayford (2010). Assessing the Impacts of the Global Economic and Financial Crisis on Vulnerable Households in Ghana. Accra: World Food Programme.

Carr-Hill, R., and E. Peart (2005). The Education of Nomadic Peoples in East Africa: Djibouti, Eritrea, Ethiopia, Kenya, Tanzania and Uganda: Review of Relevant Literature. Paris: UNESCO and African Development Bank.

Carrión, J., P. Zarate, and M. Seligson (2006). ‘The Political Culture of Democracy in Peru'. Latin America Public Opinion Project. Available at: http://www.vanderbilt.edu/lapop/ab2006/peru1-en.pdf (accessed on 26 March 2016).

Chea, S., J. Mangahas, P. Thanh An, and B. Wood (2008). Cambodia Evaluation of Aid Effectiveness. Phnom Penh: CDRI.

Chheang, V. (2013). 'The 5th Cambodia Elections: A Turning Point for the Democratic Process'. Kyoto Review of Southeast Asia. Available at: http://kyotoreview.org/uncategorized/the5th-cambodia-elections-a-turning-point-for-the-democratic-process/ (accessed 23 on April 2016).

Cueto, S., G. Guerrero, J. León, A. Zevallos, and C. Sugimaru (2009). Promoting Early Childhood Development through a Public Programme: Wawa Wasi in Peru (Promoviendo el desarrollo de la primera infancia a través de un programa público: Wawa Wasi en el Perú). (Working Paper No 51). Oxford: Young Lives.

Danish Trade Union Council for International Development Cooperation (2015). Labour Market Profile: Uganda. Copenhagen: Danish Trade Union Council for International Development Cooperation.

Debela, B.L., and S.T. Holden (2014). How Does Ethiopia's Productive Safety Net Programme Affect Livestock. Accumulation and Children's Education. Ås: Norwegian University of Life Sciences.

Dev, P., B. Mberu, and R. Pongou (2015). 'Ethnic Inequality: Theory and Evidence from Formal Education in Nigeria'. MPRA Paper No. 66358. Munich: Munich Personal RePEc Archive.

The Economist (2013). 'Cambodia's Election: Feeling Cheated'. The Economist, 29 July. Available at: http://www.economist.com/blogs/banyan/2013/07/cambodias-election (accessed on 12 April 12 2016). 
Ehrentraut, S. (2013). 'Challenging Khmer Citizenship: Minorities, the State and the International Community in Cambodia'. PhD Thesis. Potsdam: University of Potsdam.

Ekaju, J. (2011). 'An Investigation into the Relationship Between the 1997 Universal Primary Education (UPE) Policy and Regional Poverty and Educational Inequalities in Uganda (19972007)'. PhD Thesis. Glasgow: University of Glasgow.

Ferreira, F., D. Filmer, and N. Schady (2009). 'Own and Sibling Effects of Conditional Cash Transfer Programs: Theory and Evidence from Cambodia'. Policy Research Working Paper 5001. Washington, DC: World Bank.

Filmer D., and N. Schady (2009). Are There Diminishing Returns to Transfer Size in Conditional Cash Transfers? Washington, DC: World Bank.

Freeland, J. (1996). 'The Global, the National, and the Local: Forces in the Development of Education for Indigenous Peoples-the Case of Peru'. In Compare, 26(2): 167-95.

Ghana Statistical Service (2014). Ghana Living Standards Survey 6 Poverty Profile. Available at: http:/ /www.statsghana.gov.gh/docfiles/glss6/GLSS6_Poverty\%20Profile\%20in\%20Ghan a.pdf (accessed on 23 March 2016).

Government of Ghana (1998). Public Expenditure Review 1997. Accra: Ministry of Finance.

Government of Ghana (2006). Annual Education Sector Performance Report. Accra: Ministry of Education.

Government of Ghana (2007). Education Sector Performance. Accra: Ministry of Education, Science and Sports.

Government of Ghana (2016) The Complementary Basic Education Programme. Available at: http://www.cbe.ges.gov.gh/ (accessed on 2 April 2016).

Government of Uganda (2010). National Development Plan 2010/11-2014/15. Kampala: Government of Uganda.

Greenhill, R. (2013). The Age of Choice: Cambodia in the New Aid Landscape. London: Overseas Development Institute.

Hedger, E., T. Williamson, T. Muzoora, and J. Stroh (2010). Sector Budget Support in Practice: Case Study Education Sector in Uganda. London: Overseas Development Institute.

Heugh, K., C. Benson, B. Bogale, M. Yohannes (2007). Final Report Study on Medium of Instruction in Primary Schools in Ethiopia. Addis Ababa: Ministry of Education, Ethiopia

Higgins, K. (2009). 'Regional Inequality and Primary Education in Northern Uganda'. Policy Brief 2 Prepared for the Word Development Report 2009. London: Overseas Development Institute.

Hinchliffe, K. (2002). 'Public Expenditures on Education in Nigeria: Issues, Estimates and Some Implications’. Africa Region Human Development Working Paper Series. Africa Region, World Bank. Available at: http://siteresources.worldbank.org/AFRICAEXT/Resources/no_29.pdf (accessed on 28 March 2017).

Human Rights Watch (2016). 'They Set the Classrooms on Fire: Attacks on Education in Northeastern Nigeria'. Available at: https://www.hrw.org/report/2016/04/11/they-setclassrooms-fire/attacks-education-northeast-nigeria (accessed on 17 March 2016).

Huntington, E. (2008). Educating the Forgotten: Non-formal Education in Urban Kampala. Kampala: School for International Training in Uganda. 
IMF (International Monetary Fund) (2006). Cambodia: Poverty Reduction Strategy Paper. Washington, DC: International Monetary Fund.

Kabeer, N. (2010). Can the MDGs Provide a Pathway to Social Justice? The Challenge of Intersecting Inequalities. New York, NY: United Nations Development Programme.

Kingdon, G.G., A. Little, M. Aslam, S. Rawal, T. Moe, H. Patrinos, T. Beteille, R. Banerji, B. Parton, and S.K. Sharma (2014). 'A Rigorous Review of the Political Economy of Education Systems in Developing Countries'. Final Report, Education Rigorous Literature Review. London: Department for International Development

Kitamura, Y., D.B. Edwards Jr., J.H. Williams, and C. Sitha (eds) (2016). The Political Economy of Schooling in Cambodia: Issues of Quality and Equity. London: Palgrave Macmillan.

Laary, D. (2016). 'Ghana: Wealthiest now Consume nearly 7 Times more than the Poorest'. The Africa Report, 11 May. Available at: http://www.theafricareport.com/poverty.html (accessed on 12 April 2016).

Leherr, K. (2009). 'National Literacy Acceleration Programme (NALAP) Baseline Assessment'. USAID/EDC Report. Available at: http://pdf.usaid.gov/pdf_docs/Pnadw581.pdf (accessed on 28 March 2017).

Lenhardt, A., A. Rogerson, F. Guadagno, T. Berliner, M. Gebreeyesus, and A. Bayru (2015). 'One Foot on the Ground, One Foot in the Air; Ethiopia's Delivery on an Ambitious Development Agenda'. London: Overseas Development Institute.

Lenhardt, A., and E. Samman (2015). In Quest of Inclusive Progress: Exploring Intersecting Inequalities in Human Development. London: Overseas Development Institute.

Lincove, J.A. (2009). 'Determinants of Schooling for Boys and Girls in Nigeria under a Policy of Free Primary Education'. Economics of Education Review, 28: 474-84.

McCormac, M., and J. Benjamin (2008). 'Education and Fragility in Northern Uganda'. USAID. Available at: http://www.equip123.net/docs/E1-Education_Fragility_Uganda.pdf (accessed on 15 April 2016).

Maikish, A., and A. Gershberg (2008). 'Overcoming Inequality: Why Governance Matters.' Paper commissioned for the EFA Global Monitoring Report 2009. Paris: United Nations Educational Scientific and Cultural Organization.

Marcus, R, A.L. Mdee, and E. Page (2016). Anti-discrimination Policies and Programmes in Low-and Middle-income Countries: Experiences in Political Participation, Education and Labour Markets. London: Chronic Poverty Advisory Network. Available at: http:/ / www.chronicpovertynetwork.org/resources/2016/6/17/anti-discriminationpolicies-and-programmes-in-low-and-middle-income-countries-experiences-in-politicalparticipation-education-and-labour-markets. (accessed on 25 July 2016).

Mbabazi, P., J. Makaaru Arinaitwe, and G. Tumushabe (2013). 'The Political Economy of the Education Sector Policy Reform in Uganda'. Available at: http://www.must.ac.ug/sites/default/files/files/research uptake/The_political_economy_of_the_education_sector_policy_reform_in_Uganda.pdf (accessed on 27 March 2016).

Minority Rights Group International (2008). 'World Dictionary of Minorities and Indigenous Peoples: Cambodia'. Available at: http://www.refworld.org/docid/49749d441d.html (accessed on 10 July 2016). 
Minorities at Risk Project (2009). 'Minorities at Risk Dataset'. College Park, MD: Center for International Development and Conflict Management. Available at http://www.mar.umd.edu/ (accessed on 9 March 2017).

Moser, P. (2015). 'Koranic Schools in Nigeria Join the Drive for Universal Education'. UNICEF. Available at: http://www.unicef.org/education/nigeria_78459.html (accessed on 18 March 2016).

Muelle, L. (2016). 'Factores de riesgo en el bajo desempeño académico y desigualdad social en el Perú según PISA 2012'. Apuntes, 43(79): 9-45.

Murphy, P., C. Bertoncino, and L. Wang (2002). Achieving Universal Primary Education in Uganda; The 'Big Bang' Approach. Washington, DC: World Bank.

Murray, H. (2012). 'Is School Education Breaking the Cycle of Poverty for Children? Factors Shaping Education Inequalities in Ethiopia, India, Peru and Vietnam'. Policy Paper 6. Oxford: Young Lives.

National Institute of Statistics, Directorate General for Health, and ICF International (2015). Cambodia Demographic and Health Survey 2014. Phnom Penh and Rockville, MD: National Institute of Statistics, Directorate General for Health, and ICF International.

Nordic Consulting Group (2008). Evaluation of Gender Outcomes in Poverty Eradication Action Plan. Kampala: Nordic Consulting Group.

Onwuameze, N.C. (2013). 'Educational Opportunity and Inequality in Nigeria: Assessing Social Background, Gender and Regional Effects'. PhD Thesis. City of Iowa, IA: University of Iowa.

OPEC (Organization of the Petroleum Exporting Countries) (2004). 'OPEC Fund Supports Poverty Reduction Scheme in Ghana with US\$7 Million Loan'. Available at: http://www.ofid.org/NewsEvents/ArticleId/998/OPEC-Fund-supports-povertyreduction-scheme-in-Ghana-with-US-7-million-loan (accessed on 16 April 2016).

Owu-Ewie, C. (2006). 'The Language Policy of Education in Ghana: A Critical Look at the English-only Language Policy of Education'. In Selected Proceedings of the 35th Annual Conference on African Linguistics (pp. 76-85). Somerville, MA: Cascadilla Proceedings Project.

Palmieri, S. (2010). The Hidden Minorities: Representing Ethnic and Indigenous Minorities and Indigenous Peoples in Cambodia. Geneva: Inter-Parliamentary Union.

Perova, E., and R. Vakis (2009). Welfare Impacts of the 'Juntos' Program in Peru: Evidence from a Nonexperimental Evaluation. Washington, DC: World Bank.

Raheem, W.M., O.I. Oyeleye, M.A. Adeniji, and A.C. Opeyemi (2014). 'Regional Imbalances and Inequalities in Nigeria: Causes, Consequences and Remedies'. Research on Humanities and Social Sciences, 4(18).

Right to Education Project (n.d.a). 'National Constitutional Provisions-Uganda'. Available at: http://r2e.gn.apc.org/country-node/400/country-constitutional (accessed on 12 April 2016).

Right to Education Project (n.d.b). 'National Constitutional Provisions- Nigeria'. Available at: http://r2e.gn.apc.org/country-node/382/country-constitutional (accessed on 12 April 2016).

Right to Education Project (n.d.c). 'National Constitutional Provisions-Peru'. Available at: http://r2e.gn.apc.org/country-node/384/country-constitutional (accessed on 12 April 2016). 
Royal Government of Cambodia (2003). Cambodia Millennium Development Goals Report. Phnom Penh: Ministry of Planning.

Royal Government of Cambodia (2014). Education Sector Strategic Plan 2014-2018. Phnom Penh: Ministry of Education, Youth and Sport.

Salazar, M. (2011). 'Peru: Rural Education Reflects Ethnic, Socioeconomic Inequalities'. Inter-Press Service News Agency (IPS), 31 January. Available at: http://www.ipsnews.net/2011/01/perurural-education-reflects-ethnic-socioeconomic-inequalities/ (accessed on 10 May 2016).

Shepherd, A., E. Gyimah-Boadi, S. Gariba, S. Plagerson, and W.A. Musa, (2006). 'Bridging the North South Divide in Ghana. Background Paper for the World Development Report. Available at: http://www.rrojasdatabank.info/wir2006/shepherd.pdf (accessed on 28 March 2017).

Sherris, A., K. Rosekrans, and M. Chatry-komarek (2012). 'Education Reform for the Expansion of Mother-tongue Education in Ghana'. International Review of Education, 58(5): 593-618.

Snyder, S. (2008). 'The Roots and Repercussions of Educational Inequality on the Indigenous Populations of Peru'. Stanford Journal of International Relations, 10(1): 52-59.

Stasavage, D (2005). 'The Role of Democracy in Uganda's Move towards Universal Primary Education'. The Journal of Modern African Studies, 43(1): 53-73

Sumner, A. (2012) 'The New Face of Poverty: How has the Composition of Poverty in Low Income and Lower Middle-Income Countries (excluding China) Changed since the 1990s?'. IDS Working Papers, 2012(408): 1-33.

Tafere, Y., and T. Woldehanna (2012). 'Beyond Food Security: Transforming the Productive Safety Net Programme in Ethiopia for the Well-being of Children'. Working Paper 83. Oxford: Young Lives.

Thomas, A. (2003). Bilingual Education in Cambodia. Phnom Penh: Ministry of Education. Government of Cambodia.

Thompson, N.M., and L. Casely-Hayford (2008). 'The Financing and Outcomes of Education in Ghana'. RECOUP Working Paper $16 . \quad$ Available at: http://ceid.educ.cam.ac.uk/publications/WP16.pdf (accessed on 17 April 2016).

Umar, H.M., R. Ismail, and R. Abdul-Hakim (2014). 'Regional Inequality of Educational Attainment in Nigeria'. British Journal of Economics, Management and Trade, 4(3): 420-30.

UNESCO (2011). 'Ethnolingustic Groups of Cambodia'. Available at: http:/ /www.unesco.org/new/fileadmin/MULTIMEDIA/FIELD/Phnom_Penh/pdf/ethn olinguistic_groups_of_cambodia_poster.pdf (accessed on 12 May 2016).

UNESCO (2015a). 'Education for All 2015 National Review Report: Ethiopia'. Available at: http://unesdoc.unesco.org/images/0023/002317/231724e.pdf (accessed on 2 May 2016).

UNESCO (2015b). 'Education for All 2015 National Review Report: Uganda'. Available at: http://unesdoc.unesco.org/images/0023/002317/231727e.pdf (accessed on 12 April 2016).

UNESCO (2015c) 'Global Education Monitoring Report: Inequalities in Education'. Available at: http://en.unesco.org/gem-report/sites/gem-report/files/220440E.pdf (accessed on 12 April 2016).

UNESCO (2016). 'World Inequality Database on Education'. Available at: http:/ /www.educationinequalities.org/ (accessed on 12 April 2016). 
UNICEF (2012) 'Global Initiative on Out-of-School Children: Ghana Country Study'. Available at: http://www.uis.unesco.org/Library/Documents/out-of-school-children-ghana-countrystudy-2012-en.pdf (accessed on 24 April 2016).

UNICEF (2016). 'The Ghana Poverty and Inequality Report'. Available at: http://www.unicef.org/ghana/Ghana_Poverty_and_Inequality_Analysis_FINAL_Match_2 016(1).pdf (accessed on 24 April 2016).

UN Inter Agency Group for Child Mortality Estimation (2015). 'Levels and Trends in Child Mortality'. http://www.childmortality.org/files_v20/download/IGME report 2015 child mortality final.pdf (accessed on 17 July 2016).

Unison MG Consulting Services (2009). Study on Alternative Delivery Models for Primary Schooling and Primary Teacher Training for Karamoja Region. Kampala: Unison MG Consulting Services.

Vaughan, S. (2016). 'Revolutionary Democratic State Building: Party, State and People in the EPRDF's Ethiopia'. In J. Abbink and T. Hagmann (eds), Reconfiguring Ethiopia: The Politics of Authoritarian Reform. London: Routledge

Vujcich, D. (2013). 'Policy and Practice on Language of Instruction in Ethiopian Schools: Findings from the Young Lives School Survey'. Working Paper 108. Oxford: Young Lives.

Wetheridge, L., O. Kapaya, E. Unterhalter, and J. Heslop (2012). 'Transforming Education for Girls in Tanzania: End Line Research Summary Report'. Available at: http://www.actionaid.org/sites/files/actionaid/3351_ed4girlstanzaniaendfinal.pdf (accessed on 2 May 2016).

Woldehanna, T (2009). 'Productive Safety Net Programme and Children's Time Use between Work and Schooling in Ethiopia'. Working Paper 40. Oxford: Young Lives.

Woodhead, M., P. Ames, U. Vennam, W. Abebe, and N. Streuli (2009). 'Equity and Quality? Challenges for Early Childhood and Primary Education in Ethiopia, India and Peru'. Working Papers in Early Childhood Development 55. Studies in Early Childhood Transitions. The Hague: Bernard van Leer Foundation.

World Bank (2006). 'Bridging the North-South Divide in Ghana'. World Development Report Background Papers. Washington, DC: World Bank. Available at: http:/ / siteresources.worldbank.org/INTWDRS/Resources/477365-

$1327693659766 / 8397901$

1327773323392/Bridging_the_North_South_Divide_in_Ghana.pdf (accessed on 12 April 2016).

World Bank (2015). 'Government Expenditure on Education, Total (\% of GDP)'. Washington, DC: World Bank. Available at: http:// data.worldbank.org/indicator/SE.XPD.TOTL.GD.ZS (accessed on 27 March 2016).

World Bank (2016a). 'School Enrollment, Primary (Gross), Gender Parity Index (GPI)'. Washington, DC: World Bank. Available at: http://data.worldbank.org/indicator/SE.ENR.PRIM.FM.ZS?locations=ET (accessed on 14 March 2016).

World Bank (2016b) 'Peru: Overview'. Washington, DC: World Bank. Available at: http://www.worldbank.org/en/country/peru/overview (accessed on 14 March 2016). 